\title{
Article \\ Characterization of VOCs Emitted by Foliage of Grapevine cv. Isabella for Prospecting Innovative Cropping Systems
}

\author{
Arleen Rodríguez-Declet (D), Antonio Castro-Marín (D), Luca Moretti Conti, Alessandra Lombini, Fabio Chinnici (D) \\ and Adamo Domenico Rombolà *(D)
}

check for

updates

Citation: Rodríguez-Declet, A.; Castro-Marín, A.; Moretti Conti, L.; Lombini, A.; Chinnici, F.; Rombolà, A.D. Characterization of VOCs Emitted by Foliage of Grapevine cv. Isabella for Prospecting Innovative Cropping Systems. Agronomy 2022, 12, 272. https://doi.org/10.3390/ agronomy12020272

Academic Editor: Gerardo Fernández Barbero

Received: 21 December 2021

Accepted: 18 January 2022

Published: 21 January 2022

Publisher's Note: MDPI stays neutral with regard to jurisdictional claims in published maps and institutional affiliations.

Copyright: (C) 2022 by the authors. Licensee MDPI, Basel, Switzerland. This article is an open access article distributed under the terms and conditions of the Creative Commons Attribution (CC BY) license (https:// creativecommons.org/licenses/by/ $4.0 /)$.
Department of Agricultural and Food Sciences, Alma Mater Studiorum University of Bologna, Viale G. Fanin, 44, 40127 Bologna, Italy; arleen.rodriguez3@unibo.it (A.R.-D.); antonio.castromarin2@unibo.it (A.C.-M.); luca.moretticonti@studio.unibo.it (L.M.C.); alessandra.lombini@unibo.it (A.L.); fabio.chinnici@unibo.it (F.C.)

* Correspondence: adamo.rombola@unibo.it

\begin{abstract}
Volatile organic compounds play an important role in communication within plants as well as with other organisms. In this work we identified the volatile organic compounds (VOCs) emitted from the foliage of the grapevine cv. Isabella, a largely known hybrid of Vitis vinifera $\times$ Vitis labrusca. Our data show 25 VOCs emitted by cv. Isabella. Different compound classes were found, including alcohols, hydrocarbons, esters, terpenes, ketones, and a green leaf volatile (GLV). The study highlighted differences between volatile profiles for diurnal and nocturnal treatments. The compounds: trans-3dodecene, 5,5 dibutylnonane, ethyl 2-methyllactate, 2-hexanol, 3-ethyl-2-heptanol, 3-nonanol, and 2-nonanol, have not been previously reported for Vitis vinifera foliage. Notably, eight compounds emitted by cv. Isabella, 1-heptanol, 1-octanol, 2-hexanol, 2-nonanone, $\beta$-pinene, camphene, cishexenyl acetate, and phenethyl alcohol, are of relevant interest for their role in plant defense. New knowledge on the emission of these compounds in cv. Isabella can help to understand the mechanisms of pathogen tolerance of this genotype and could be an important step in prospecting innovative cropping systems.
\end{abstract}

Keywords: VOCs emission; Vitis labrusca $\times$ Vitis vinifera; agroecological systems; phenethyl alcohol

\section{Introduction}

Volatile organic compounds (VOCs) represent a large and structurally diverse group of secondary metabolites produced by plants. VOCs are substances with low molecular weight [1] which are formed through many biochemical pathways, constitutively and/or after stress induction, with nearly all plant organs being able to secrete and emit a number of these compounds [2-5]. They can be emitted throughout the life cycle of the plant or, more commonly, at specific developmental stages such as leaf maturation, senescence, flowering, and fruit ripening [3]. The main classes of VOCs emitted by plants belong to the group of terpenoids, fatty-acid-derived C6-volatiles and derivatives, phenylpropanoid aromatic compounds as well as certain alkanes, alkenes, alcohols, esters, aldehydes, and ketones [6,7].

Plant emissions of VOCs can be influenced by both biotic and abiotic stresses and play an important role in communication within plants as well as with other organisms, such as the attraction of insects (herbivorous insects and pollinators) [4]. VOCs can repel herbivores or attract herbivore's parasitoids/predators [8,9]. In addition, VOCs can directly influence the development of pathogens [7] and prime plant defense mechanisms [10,11], and signal the activation of defense and control mechanisms against pests and pathogens [12]. Plant defense mechanisms involve the emission of well-known defense compounds (i.e., MeSA, MeJA, terpenoids, etc.), during pathogen and pest attack, highlighting the role of VOCs in plant-pathogen/pest interactions $[13,14]$. Examples show that defensive volatile chemicals can lead to an influence on multitrophic interactions, as a recent study showed that an infection of canola by the root pathogen Plasmodiophora brassicae Woronin reduced oviposition 
by bertha army worm, Mamestra configurata Walker (Lepidoptera: Noctuidae) [15]. Further, VOCs released from resistant plants can trigger specific defensive responses in other parts of the plant itself, and/or to neighboring plants of various species [12].

The Vitis genus is highly diverse with eighty species identified, and composed of several thousand varieties [16]. Consequently, considering that VOCs vary based on genotype, several profiles of different genotypes of Vitis spp. have been described, mostly focused on grape berries for oenological purposes [17-19]. Furthermore, a qualitative investigation of VOCs in cv. Moscato bianco (Vitis vinifera) clearly differentiated all vegetative organs confirming the specialization in volatile production among different organs [20]. Volatile emissions have also been described in Vitis root tissue [21]. In wild grapevine (Vitis vinifera subsp. sylvestris) sexual dimorphism was described in floral scent [22], with some VOCs involved in the attraction of well-known inflorescence visitors [23,24].

Differences in VOC profiles between downy mildew (Plasmopara viticola)-resistant and -susceptible grapevine genotypes have been reported [25-28]. Few studies have characterized the VOCs released by grape foliage, with some in vivo studies on cv. Marselan [29], cv. Chardonnay [30], cv. Pinot noir [31], and grapevine leaves of plants of cv. Sangiovese associated with arbuscular mycorrhizal fungi [32]. Fewer data are available on grapevine diurnal and nocturnal rhythms [31,33]. Diurnal and nocturnal rhythm could influence grapevine plant pathogens and insects. For example, the pests European grapevine moth Lobesia botrana (Lepidoptera: Tortricidae) and European grape berry moth Eupoecilia ambiguella (Lepidoptera: Tortricidae) are crepuscular $[34,35]$. In addition, seasonal changes determine different susceptibility to common pests and diseases that attack grapevine, for example downy mildew symptoms mostly occur during springtime [36].

The Isabella cultivar is an interspecific spontaneous crossing of Vitis vinifera and Vitis labrusca, of American origin, which shows resistance to powdery mildew (Erysiphe necator), bunch rot (Botrytis cinerea), and tolerance to downy mildew (Plasmopara viticola), cultivated worldwide for juice, table grapes, and wine production [37]. Previous studies highlight the rich inherent antioxidant levels in the seed, stalk, and leaf components of cv. Isabella [38]. However, little is known about the VOCs emitted by the cultivar, in particular from epigeic plant tissues.

Grapevine management practices include fertilization, irrigation, soil and canopy management, and plant protection practices. Several pests and diseases affect grapevine production; thus, an intensive pesticide schedule is often required to meet production standards [39]. Nevertheless, it has been demonstrated that a continuous use of plant protection products has several negative implications for the environment and human health $[40,41]$. Consequently, there is a strong need to explore and re-valorize strategies to achieve sustainable production standards. VOCs can be a natural and agroecological solution to enhance crop defense mechanisms [42].

Thus, the main objective of the present study was to identify and characterize the VOCs emitted from foliage of the grapevine cv. Isabella during diurnal and nocturnal periods under controlled conditions. In addition, the experiments were performed in two different seasons (fall and spring).

The profiling of VOCs emitted by cv. Isabella can contribute to the understanding of plant defense mechanisms, as plants are able to produce chemical compounds that influence the growth and development of pathogens, pests, and weeds [3,7,13,42]. Knowledge on cv. Isabella VOC emissions could lead to the prospect of innovative sustainable systems based on intercropping.

\section{Materials and Methods}

\subsection{Plant Material}

The present study was carried out through two experiments performed under a controlled environment in a greenhouse located at the Department of Agriculture and Food Sciences at the University of Bologna, Italy. 
Plants of the grapevine genotype Isabella (Vitis vinifera $\times$ Vitis labrusca), grafted on rootstock 225 Ruggeri in February 2017, were obtained from a nursery. Vines were maintained under refrigeration $\left(4^{\circ} \mathrm{C}\right)$ until being planted in the greenhouse at the end of June 2019. The first experiment was conducted in October 2019. Pruning was performed at the end of December 2019, as plants reached two years. In June 2020, the second experiment was performed. For the duration of the study, plants were watered to field capacity, and full-strength Hoagland solution was regularly provided to maintain satisfactory plant growth conditions. The plants sampled were similar in growth (shoot length and numbers of leaves) and nutritional status. No inflorescences or bunches were present. Only plants with a healthy appearance (visual inspection) were used for experiments.

\subsection{Collection of VOCs}

VOC sampling included two distinct collection times, a nocturnal and a diurnal period in fall and the following spring. The sampling was set up for a total of four hours for the diurnal collection time and twelve hours for the nocturnal collection time. Similar sampling durations have been employed in grapevine and other species [29-31,43]. While the nocturnal period extended to $12 \mathrm{~h}$, the diurnal period was limited to $4 \mathrm{~h}$ to avoid possible interferences due to more intense gas exchanges.

The collection of the VOCs emitted by the cv. Isabella foliage was performed with the cartridge adsorbent Radiello ${ }^{\mathrm{TM}}$ BTEX/VOCs (RAD130, Sigma-Aldrich S.r.l., Milan, Italy), which acts as a diffusive sampler, used to quantify the VOCs emitted in the confined atmosphere surrounding the plant, as described in similar experiments [44].

The system for enclosing the plants (Figure 1) was a modified version of the system described by Kigathi et al. [43]. For the enclosure, a low-density polyethylene (PE.Ld) neutral food grade bag (20 L) (LDPE MOCA 2020, Cristianpack S.r.l., Osimo (AN), Italy) was used. The bag enclosed the foliage (shoots with approximately 40 and 27 leaves for the first and second experiment, respectively; spur and trunk) of each individual plant, with a respective cartridge placed inside the enclosed system. To avoid any interference the bag was supported from the outside and the rootstock and soil was separated from the upper part by closing the system from the scion up. After each collection period the cartridges were put in the provided volatile-free tube and immediately taken to the laboratory for analysis. Empty bags, without enclosing a plant, were also used to see any background noise, and traces of VOCs were detected (3-methyl-3-pentanol, 4-methyl tetradecane, 4-methyl-2-pentanol, methyl palmitate, octadecyldimethylsilvyl ether).

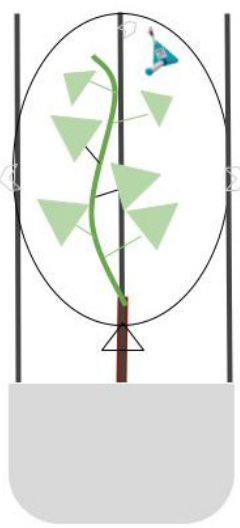

Figure 1. Conceptual sketch of the collection system by enclosed plant foliage and cartridge absorbent Radiello $^{\mathrm{TM}}$.

\subsection{First Experiment (Fall 2019)}

The treatment consisted of three biological replicates, each composed by one single plant. The same plants were used for both the diurnal and nocturnal collection times. Plants presented two shoots with an average length of $1.15 \mathrm{~m}$ and about 40 leaves. The nocturnal 
sampling was initiated on 30 October 2019 (7:00 p.m.) and samples were collected the following day (7:00 a.m.) after $12 \mathrm{~h}$ of exposure; the diurnal collection (8:30-12:30 a.m.) period (4 h) immediately followed. Condensation moisture, associated with plant transpiration, was observed at the end of the diurnal collection time. During sampling, the temperatures were between $18.1{ }^{\circ} \mathrm{C}$ and $16.3{ }^{\circ} \mathrm{C}$. Relative humidity $(\mathrm{RH})$ ranged from $82 \%$ to $84 \%$ in the nocturnal period and from $84 \%$ to $88 \%$ in the diurnal period.

\subsection{Second Experiment (Spring 2020)}

On 4 June 2020, the second experiment was initiated. This experiment consisted of six biological replicates of one plant for every diurnal and nocturnal collection time. The sampling and collection system was consistent with the first experiment. The nocturnal period went from 7:00 p.m. to 7:00 a.m., and the diurnal period went from 6:30 to 10:30 a.m. (solar hour). Condensation moisture was observed at the end of the diurnal collection time. To achieve the twelve hours of darkness, as in the first experiment, for the nocturnal collection time, plant exposure to light was prevented by a dark cover. The diurnal and nocturnal collections were performed on different sets of plant. Plants presented three shoots with an average length of $38 \mathrm{~cm}$ and about 27 leaves. Temperature and relative humidity during the diurnal sampling period were on average $21.7^{\circ} \mathrm{C}$ and $83 \% \mathrm{RH}$, and for the nocturnal sampling period an average of $20.1^{\circ} \mathrm{C}$ with an average $\mathrm{RH}$ of $89 \%$.

\subsection{Analysis of Volatile Organic Compounds by GC-MS}

Volatile organic compounds were extracted according to the manufacturer's protocol as modified by Joos et al. [45]. For the extraction, the cartridges were submitted to solvent desorption by using ultrapure analytical grade dichloromethane (Merck, Darmstadt, Germany). The use of this solvent avoided some peak tailing problems encountered in our specific chromatographic conditions when using $\mathrm{CS}_{2}$, another solvent commonly used to desorb the cartridges.

The extraction was started by adding $2 \mathrm{~mL}$ of dichloromethane and $100 \mu \mathrm{L}$ of a 2-octanol solution at $500 \mathrm{mg} \mathrm{L}^{-1}$ as an internal standard directly in the cartridge glass tube without drawing out the cartridge. The tube, containing the cartridge and internal standard, was agitated from time to time for a total of $30 \mathrm{~min}$. The cartridge was then discarded, and the solvent was transferred to a vial to be concentrated to a final volume of $200 \mu \mathrm{L}$ under a stream of pure nitrogen $\left(\mathrm{N}_{2}\right)$, prior to GC-MS analysis.

The Trace GC ultra-apparatus coupled with a Trace DSQ mass selective detector (Thermo Fisher Scientific, Milan, Italy) was equipped with a fused silica capillary column Stabilwax DA (Restek, Bellefonte, PA, USA; $30 \mathrm{~m}, 0.25 \mathrm{~mm}$ i.d., and $0.25 \mu \mathrm{m}$ film thickness). The carrier gas was He at a constant flow of $1.0 \mathrm{~mL} / \mathrm{min}$. In accordance with Castro Marin et al. [46], the GC programmed temperature was as follows: $45^{\circ} \mathrm{C}$ (held for $3 \mathrm{~min}$ ) to $100{ }^{\circ} \mathrm{C}$ (held for $1 \mathrm{~min}$ ) at $3{ }^{\circ} \mathrm{C} / \mathrm{min}$, then to $240{ }^{\circ} \mathrm{C}$ (held for $10 \mathrm{~min}$ ) at $5{ }^{\circ} \mathrm{C} / \mathrm{min}$. Injection was performed at $250{ }^{\circ} \mathrm{C}$ in splitless mode and the injection volume was $1 \mu \mathrm{L}$. Detection was carried out by electron ionization (EI) mass spectrometry in full scan mode, using ionization energy of $70 \mathrm{eV}$. The transfer line interface was set at $220{ }^{\circ} \mathrm{C}$ and ion source at $260^{\circ} \mathrm{C}$. The mass acquisition range was $m / z 30-400$ and the scanning rate

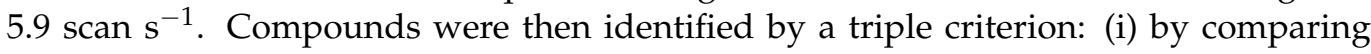
their mass spectra and retention time with those of authentic standards, (ii) compounds lacking standards were identified after matching their respective mass spectra with those present in the commercial libraries NIST 08 and Wiley 7, and (iii) matching their Linear Retention Index (LRI) obtained under our conditions with already published LRI on similar polar columns. VOCs were quantified from the total ion current according to the internal standard method. In Table 1, the compounds identified by comparison with pure standards have been highlighted. 
Table 1. Rate of emission ( $\mu$ g plant ${ }^{-1} \mathrm{~h}^{-1}$ ) of volatile organic compounds (VOCs) identified to be emitted by foliage of cv. Isabella. ${ }^{1}$ VOCs were collected during diurnal $(4 \mathrm{~h})$ and nocturnal $(12 \mathrm{~h})$ periods under controlled conditions in two different seasons (fall 2020 and spring 2020), by enclosed plant foliage and cartridge absorbent Radiello ${ }^{\mathrm{TM}}$.

\begin{tabular}{|c|c|c|c|c|c|c|c|c|}
\hline No. & RI & Compound & Diurnal & Nocturnal & & Diurnal & Nocturnal & \\
\hline & & & \multicolumn{2}{|c|}{ Fall 2019} & & \multicolumn{2}{|c|}{ Spring 2020} & \\
\hline \multicolumn{9}{|c|}{ Terpenes } \\
\hline 1 & 1078 & Camphene & $0.0014 \pm 0.0008$ & $0.0012 \pm 0.0005$ & & $0.0058 \pm 0.0022$ & $0.0011 \pm 0.0006$ & * \\
\hline 2 & 1105 & $\beta$-pinene ${ }^{a}$ & $0.0056 \pm 0.0014$ & $0.0050 \pm 0.0011$ & & $0.0795 \pm 0.0181$ & $0.0034 \pm 0.0010$ & ** \\
\hline \multicolumn{9}{|c|}{ Hydrocarbons } \\
\hline 3 & 1126 & Ethylbenzene & nd & $0.0014 \pm 0.0008$ & * & nd & nd & \\
\hline 4 & 1202 & Dodecane $^{\mathrm{a}}$ & nd & nd & & $0.5596 \pm 0.2272$ & $0.3431 \pm 0.0352$ & * \\
\hline 5 & 1240 & 1-hexadecene & nd & nd & & nd & $0.0205 \pm 0.0246$ & \\
\hline 6 & 1257 & trans-3-dodecene & $0.0018 \pm 0.0014$ & $0.0017 \pm 0.0004$ & & nd & nd & \\
\hline 7 & 1298 & Tridecane $^{\mathrm{a}}$ & nd & nd & & $0.3837 \pm 0.2009$ & $0.1641 \pm 0.0514$ & * \\
\hline 8 & 1314 & Butylbenzene & nd & $0.0010 \pm 0.0014$ & & nd & nd & \\
\hline 9 & 1392 & 5,5 dibutylnonane & nd & nd & & $0.0748 \pm 0.0773$ & $0.0360 \pm 0.0106$ & \\
\hline 10 & 1402 & Tetradecane $^{\mathrm{a}}$ & nd & nd & & $0.5657 \pm 0.2668$ & $0.2092 \pm 0.1280$ & * \\
\hline
\end{tabular}

\section{Green leaf volatiles}

(GLVs)

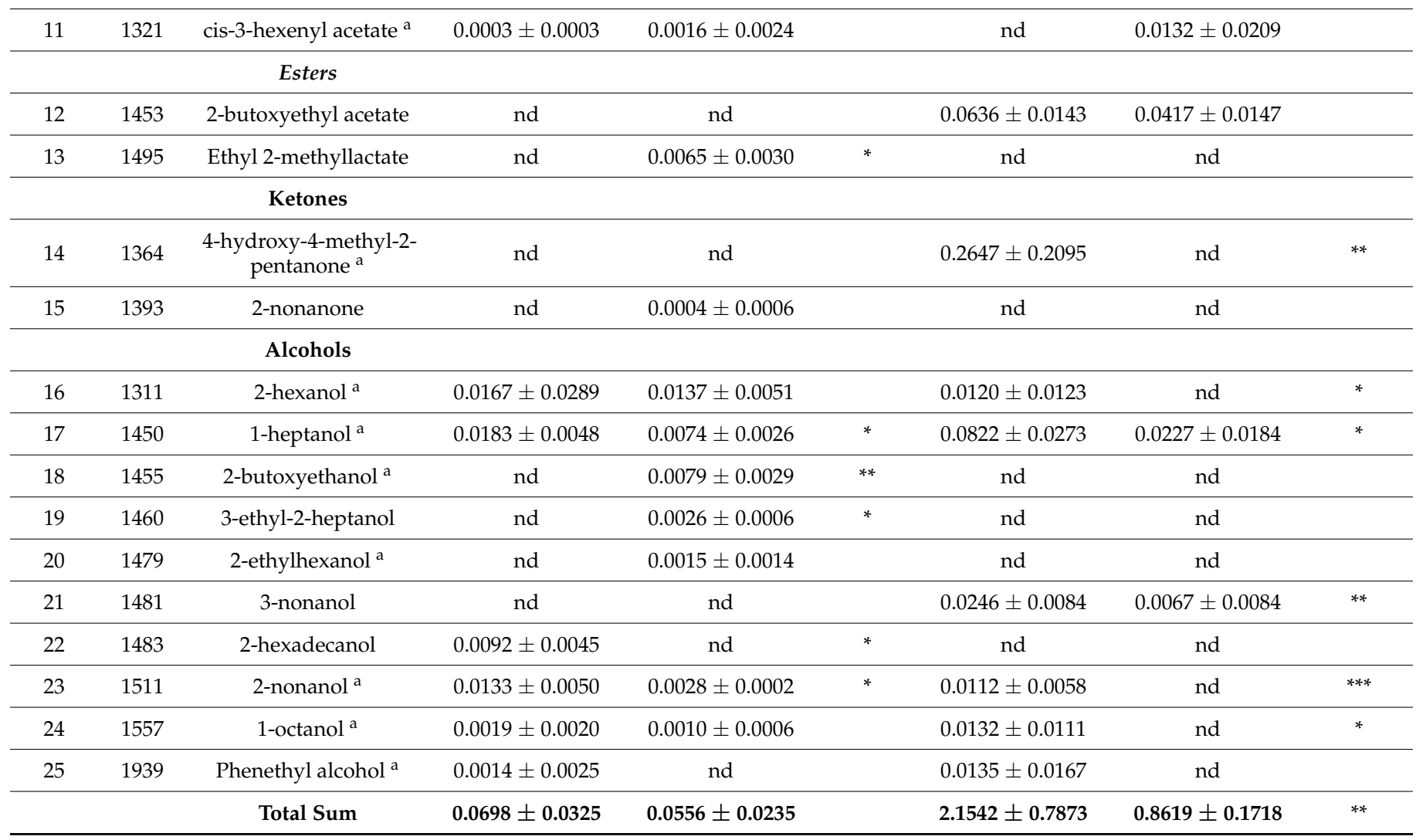

Identification of compounds by comparing with mass spectra, retention time with those of authentic and already published Linear Retention Index (LRI) on polar columns. Data represent the mean of 3 replicates (2019) and 6 replicates $(2020) \pm$ standard deviation. $n d=$ not detected. Significant differences are referred to diur$\mathrm{nal} /$ nocturnal collection time within each experiment. Significant at ${ }^{*} p \leq 0.05,{ }^{* *} p \leq 0.01,{ }^{* * *} p \leq 0.001$ (SNK-test). ${ }^{\text {a }}$ Compound identified with pure standard. 
For each volatile compound, the emission rate was calculated and expressed as micrograms per plant per hour $\left(\mu \mathrm{g}\right.$ plant $^{-1} \mathrm{~h}^{-1}$ ) to account for the cartridge exposure time during sampling (Table 1). To calculate the emission rate of each volatile, the number of compounds adsorbed by the cartridge, obtained as described before, was referred to the pertinent exposure time ( 4 or $12 \mathrm{~h}$ ) and were expressed as $\mu \mathrm{g}$ plant ${ }^{-1} \mathrm{~h}^{-1}$.

\subsection{Statistical Analysis}

Data were submitted to statistical analysis using the MATLAB ver. R2021a (Boston, MA, USA). One-way analysis of variance (ANOVA) was carried out to compare diurnal/nocturnal collection time within each experiment. Means were compared by the Student-Newman-Keuls (SNK) test $(p \leq 0.05)$.

\section{Results}

Our study identified a total of 25 volatile organic compounds emitted by the foliage of the cv. Isabella (Table 1). Representative chromatograms of the 4 different sampling (diurnal and nocturnal in seasons 2019 and 2020) are shown in Figure S1. Among the numerous types of VOCs described, a variety of compound classes were found: ten alcohols, eight hydrocarbons, two esters, two terpenes, two ketones, and one green leaf volatile (GLV) (Table 1).

\subsection{First Experiment (Fall 2019)}

A total of 17 volatile organic compounds were identified in the diurnal and nocturnal collection times performed in the first year trial (Table 1). Compounds 2-hexadecanol and phenethyl alcohol were present only in the diurnal sampling, and ethylbenzene, butylbenzene, 2-nonanone, 2-butoxyethanol, 3-ethyl-2-heptanol, 2-ethylhexanol, and ethyl 2-methyllactate were found to be emitted by the plant exclusively during the night (Table 1).

\subsection{Second Experiment (Spring 2020)}

A total of 16 VOCs were identified to be emitted by the foliage of the cv. Isabella in the diurnal and nocturnal treatments performed in the second experiment (Table 1). Compounds 2-hexanol, 4-hydroxy-4-methyl-2-pentanone, 2-nonanol, 1-octanol, and phenethyl alcohol were identified only during the diurnal collection time and 1-hexadecene and cis-3-hexenyl acetate were found only during the nocturnal period (Table 1). In the second experiment, total VOC concentration increased up to $35 \%$ when compared with the first experiment.

\section{Discussion}

Terpenes, hydrocarbons, green leaf volatiles, esters, ketones, and alcohols were detected as VOCs emitted by foliage of cv. Isabella. Alcohols (10 compounds) and hydrocarbons (8 compounds) were the predominant classes in both diurnal and nocturnal conditions. Similar results were seen in Tasin et al. [30], with hydrocarbons as the most represented class emitted from leaves of $\mathrm{cv}$. Chardonnay.

The predominant compounds detected in the first experiment (fall), for the diurnal and nocturnal periods, were alcohols: 1-heptanol, 2-hexanol, and 2-butoxyethanol (Table 1). As for the second experiment (spring), the predominant compounds identified for both diurnal and nocturnal collection times were tetradecane and dodecane, belonging to the hydrocarbons class (Table 1).

The second experiment, compared to the previous one, was characterized by a different photoperiod (longer light period, shorter dark period), higher light intensity and temperature, lower air relative humidity, and older plants which presumably modified the VOC emission. In Vitis spp., a comparison of the complete odor bouquet of cultivars MüllerThurgau, Regent, and Pinot noir during the whole growing season revealed clear differences between the phenological stages and few between the cultivars [47]. The prevalence of hydrocarbons in the VOCs emitted by plants in the spring experiment may be mainly 
attributed to leaf age and season. In grapevine, it has been reported that branches with young leaves collected in spring emit hydrocarbons, but not alcohols [30]. The prevalence of alcohols in the fall experiment, may be due to a predominant emission of oxygenated VOCs by old leaves near senescence, as reported in other species [48].

The most abundant volatiles emitted in vivo from leaf-bearing shoots of cv. Chardonnay was (E)-ocimene [30], (E,E)- $\alpha$-farnesene in cv. Pinot Noir [31], and (E)-2-hexenal in leaf tissue of cv. Sangiovese [32]. In young and mature leaves of cv. Moscato bianco, geraniol and benzyl alcohol were the alcohols found in highest concentrations [20].

In our conditions, cv. Isabella released seven volatiles (5,5 dibutylnonane, ethyl 2methyllactate, 3-ethyl-2-heptanol, 2-hexanol, 2-nonanol, 3-nonanol, and trans-3-dodecene) which have not been previously reported in foliage (shoots and trunk) of grapevine.

Six of these compounds (5,5 dibutylnonane, 3-ethyl-2-heptanol, 2-hexanol, 2-nonanol, 3-nonanol, and trans-3-dodecene) have been found in other species [49-53]. Interestingly, trans-3-dodecene was found in rice cells elicited by rice blast (Magnaporthe oryzae) [54]. The compound 2-hexanol, known to elicit responses in several insects [55,56], has been recently found in grape berries [57]. The possible roles played by these compounds in cv. Isabella should be ascertained by further research.

VOCs identified in Isabella could play a role in various defense, physiological, and other functions, such as communication within and between plants and other organisms [4,12], attraction and repulsion of insects [58], interactions with pathogens [7], and plant defense mechanisms $[10,11,58]$.

Data indicates that there are significant changes between diurnal and nocturnal emission times. In the 2019 experiment (fall), compounds 1-heptanol and 2-nonanol exhibited higher emission rates during daylight. Concerning the second experiment (spring 2020), camphene, $\beta$-pinene, dodecane, tridecane, 4-hydroxy-4-methyl-2-pentanone, tetradecane, 1-heptanol, 3-nonanol, 2-nonanol, and 1-octanol emission rates were found higher during the diurnal collection time (Table 1).

In the nocturnal collection times, considering both years, eight compounds (ethylbenzene, 1-hexadecene, butylbenzene, ethyl 2-methyllactate, 2-nonanone, 2-butoxyethanol, 3-ethyl-2-heptanol, 2-ethylhexanol) were found that were not identified in the diurnal collection times (Table 1).

Some compounds showed distinct day/night emission behaviors. In the spring experiment, cis-3-hexenyl acetate was observed only during nighttime. In previous studies cis-3-hexenyl acetate showed distinct emission bursts, in apple and grapevine, following the daily light switch-off [31]. Cis-3-hexenyl acetate shows an influence on certain insects with crepuscular behavior. For instance, when emitted by grapevine, it served as an attractant for the crepuscular insect L. botrana [30]. Another example of an important Dipteran insect attracted to cis-3-hexenyl acetate is the wheat midge, Sitodiplosis mosellana (Diptera: Cecidomyiidae), a twilight-active wheat pest $[59,60]$. In contrast to cis-3-hexenyl acetate, in the spring experiment, 2-hexanol, 4-hydroxy-4-methyl-2-pentanone, 2-nonanol, and 1-octanol were detected only in the diurnal period. In the fall experiment, 2-hexadecanol was seen only in the diurnal period. Phenethyl alcohol was found only during the diurnal collection time in both experiments (Table 1).

VOCs released by grape foliage were reported to follow diurnal and nocturnal rhythms [31,33], which is a typical occurrence in plants [61]. In young leaves of plantlets of Vitis vinifera cv. Marselan, monoterpenes showed an overall day/night emission rhythm, with lower emission rates observed during the night phase; similarly, sesquiterpenes displayed a diurnal course with maximum rates close to the end of the light phase [29].

Our data suggests that distinct collection periods (which differed in terms of light intensity, temperature, and relative humidity) may influence the emission of the VOCs in cv. Isabella. In addition, differences between years were recorded (Table 1), which could be due in part to the different climatic conditions between the seasons (late spring and fall) and the phenological stage of the vines. 
The emission of certain compounds was found to vary with light intensity [62]. Nonetheless, light seems to be correlated with temperature; for instance, the emission rates from beech (Fagus sylvatica L.) and sunflower (Helianthus annuus L.) plants were seen to be affected by light intensity as well as by temperature, and it was stated that these two factors should be considered simultaneously [63]. With terpenes, the emission occurs from storage structures and is generally separate from photosynthesis as it may occur at night [64]. This may explain why camphene and $\beta$-pinene, the only terpenes found in $\mathrm{cv}$. Isabella, were emitted at a similar rate in both diurnal and nocturnal collection times in the first experiment (Table 1). Notably, Isabella leaves are characterized by the presence of dense trichomes [65] and cuticular waxes [66], which might have contributed as storage structures for terpene emissions, as reported in other species $[67,68]$. Terpenes play multiple roles in mediating antagonistic and beneficial interactions among organisms $[69,70]$ and are involved in plant-to-plant communication and signaling [71].

Temperature can also contribute to explaining the differences among the diurnal and nocturnal collection times. VOCs are normally emitted as temperature-dependent behavior; therefore, higher temperatures lead to a faster change from liquid/solid phases to the gas phase which implies an increase in emissions [72], as noted during the diurnal period (2020) with significantly higher emissions during the diurnal collection time (Table 1) when higher temperatures were registered. Additionally, volatiles are also released from intact storage structures by diffusion in a temperature-dependent way, so higher emissions are liberated from storage under warmer conditions [73].

Terpenes, as discussed before, are known to be released by storage structures; in spring 2020 (warmer temperatures than fall 2019), they were found to be much more emitted during diurnal than nocturnal sampling. Increased temperature can be considered one of the reasons for higher rates in the majority of compounds found during the diurnal collection time in both the first and second experiment (Table 1). Humidity has been reported to have significant effects on volatile emissions as well. For instance, factors of significance during a trial for apple tree emissions under field conditions were temperature and relative humidity [74]. Furthermore, high humidity may also lead to a swelling and to the consequent explosion of the structures containing storage pools while temporarily opening the stomata. This would allow the release of large pools of VOCs produced by leaf cells [3]. Nonetheless, emission patterns can be induced by light or darkness, and besides light-induced emission cycling, the emission of some volatiles can be modulated by the endogenous biological clock [61].

During the second experiment (2020), higher emission rates were recorded compared to the first experiment (2019), during both diurnal and nocturnal collection times (Table 1), as a consequence of the different environmental conditions (temperature, humidity, etc.) and plant canopy features (canopy structure, leaf age, etc.). Compounds 1-heptanol, 1-octanol, 2-hexanol, 2-nonanone, $\beta$-pinene, camphene, cis-3-hexenyl acetate, and phenethyl alcohol, identified in our study (Table 1), have been reported as of relevant interest for their plant protection roles in Vitis spp. (phenethyl alcohol [27]; 2-nonanone [75]) and in other species [76-81]. Interestingly, phenethyl alcohol was found to be emitted by the resistant Vitis genotypes Kober 5BB and Solaris and showed promising inhibitory effects against $P$. viticola [27]. In that investigation, phenethyl alcohol was present in the leaves at significant concentrations before inoculation, implying its possible contribution to disease reduction in systemic parts of locally attacked plants and in neighboring plant receivers [27]. It is a compound also found in the profile VOCs of the yeast Aureobasidium pullulans which was active against postharvest fruit pathogens [82].

Plants that express resistance emit VOCs that can trigger resistance responses in undamaged neighbors by different mechanisms, such as the priming or induction expression of resistance genes in the receiver or direct inhibitory effects on microbial pathogens [83]. In our experiments, the foliage consisted of intact shoots bearing leaves with no signs of pathogen inoculation or wounds, which suggests that VOCs were constitutively emitted. Our findings open the door for prospective innovative agronomic strategies. It has 
been demonstrated that volatiles emitted by intact plants can be adsorbed by neighboring species, with their subsequent release observed in both laboratory and field conditions [82]. Many intercropping examples have shown effective benefits in controlling and/or reducing pests and diseases [84-88].

Notably, volatile compounds of intact Isabella grapes revealed their inhibitory action on the formation and pathogenicity of downy mildew (Botrytis cinerea) in vitro and in situ, as when clusters of the cv. Isabella (resistant) were placed next to clusters of the Vitis vinifera cv. Roditis (susceptible) [89] or fruits of kiwifruit of cv. Hayward [90], inoculated with B. cinerea, pathogen growth and/or incidence was suppressed. The uniqueness of the compounds present in cv. Isabella suggests they play a role in its well-known tolerance to main fungal pathogens, such as downy mildew (biotroph), powdery mildew (biotroph) and bunch rot (necrotrophy) [37]. These pathogens are relevant during the springtime, and bunch rot also constitutes a main concern during berry ripening. They are affected by morphological (i.e., trichomes, bunch compactness) [65,91], anatomical (i.e., cuticle wax) [66], and physiological (i.e., degree of stomatal opening) [92] traits, secondary metabolites including VOCs $[1,6,7,27]$.

VOCs can be a natural and agroecological solution to enhance crop defense via both priming and induction mechanisms [42], and the possible benefits of VOCs in intercropped systems, with cultivars tolerant to main fungal pathogens, such as Isabella, could be considered for future research.

\section{Conclusions}

Volatile organic compounds emitted by the foliage of the cv. Isabella (Vitis vinifera $\times$ Vitis labrusca) were characterized. Seven VOCs were not reported before as volatiles emitted by Vitis vinifera foliage. The study demonstrated distinct volatile profiles for diurnal and nocturnal collection times.

Eight compounds emitted by cv. Isabella, 1-heptanol, 1-octanol, 2-hexanol, 2-nonanone, $\beta$-pinene, camphene, cis-3-hexenyl acetate, and phenethyl alcohol, have been reported as of relevant interest for their possible involvement in plant defense. The uniqueness of the compounds present in cv. Isabella suggests they play a role in its well-known tolerance to main fungal pathogens.

The characterization of VOCs emitted by $\mathrm{cv}$. Isabella can be a useful contribution to understanding plant defense mechanisms of pathogen tolerance and could be an important step in the perspective of designing innovative agroecological cropping systems.

Supplementary Materials: The following supporting information can be downloaded at: https: / / www.mdpi.com/article/10.3390/agronomy12020272/s1, Figure S1: Representative Total Ions Chromatograms of VOCs emitted by foliage of grapevine cv. Isabella following diurnal (2019 D and $2020 \mathrm{D})$ and nocturnal (2019 N and $2020 \mathrm{~N})$ sampling in 2019 and 2020. At $17.00 \mathrm{~min}$ the peak of 2-octanol (Internal Standard).

Author Contributions: Conceptualization, A.D.R.; methodology, A.D.R. and F.C.; investigation, A.R.-D., A.C.-M. and L.M.C.; writing-original draft preparation, A.R.-D., A.C.-M. and L.M.C.; writing-review and editing, A.R.-D., A.C.-M., A.L., F.C. and A.D.R.; supervision, F.C. and A.D.R. All authors have read and agreed to the published version of the manuscript.

Funding: This research received no external funding.

Data Availability Statement: The authors declare that the data supporting this study are available from the corresponding author on reasonable request.

Acknowledgments: The authors would like to thank the nursery Vivai Maiorana for providing the cv. Isabella plants.

Conflicts of Interest: The authors declare no conflict of interest. 


\section{References}

1. Dudareva, N.; Pichersky, E.; Gershenzon, J. Biochemistry of Plant Volatiles. Plant Physiol. 2004, 135, 1893-1902. [CrossRef] [PubMed]

2. Delory, B.M.; Delaplace, P.; Fauconnier, M.-L.; du Jardin, P. Root-Emitted Volatile Organic Compounds: Can They Mediate Belowground Plant-Plant Interactions? Plant Soil 2016, 402, 1-26. [CrossRef]

3. Loreto, F.; Schnitzler, J.-P. Abiotic Stresses and Induced BVOCs. Trends Plant Sci. 2010, 15, 154-166. [CrossRef]

4. $\quad$ Loreto, F.; Dicke, M.; Schnitzler, J.-P.; Turlings, T.C.J. Plant Volatiles and the Environment. Plant Cell Environ. 2014, 37, 1905-1908. [CrossRef] [PubMed]

5. $\quad$ Farré-Armengol, G.; Fernández-Martínez, M.; Filella, I.; Junker, R.R.; Peñuelas, J. Deciphering the Biotic and Climatic Factors that Influence Floral Scents: A Systematic Review of Floral Volatile Emissions. Front. Plant Sci. 2020, 11, 1154. [CrossRef] [PubMed]

6. Maffei, M.E. Sites of Synthesis, Biochemistry and Functional Role of Plant Volatiles. S. Afr. J. Bot. 2010, 76, 612-631. [CrossRef]

7. Hammerbacher, A.; Coutinho, T.A.; Gershenzon, J. Roles of Plant Volatiles in Defence against Microbial Pathogens and Microbial Exploitation of Volatiles. Plant Cell Environ. 2019, 42, 2827-2843. [CrossRef] [PubMed]

8. De Moraes, C.M.; Lewis, W.J.; Paré, P.W.; Alborn, H.T.; Tumlinson, J.H. Herbivore-Infested Plants Selectively Attract Parasitoids. Nature 1998, 393, 570-573. [CrossRef]

9. Dicke, M.; Baldwin, I.T. The Evolutionary Context for Herbivore-Induced Plant Volatiles: Beyond the 'Cry for Help'. Trends Plant Sci. 2010, 15, 167-175. [CrossRef]

10. Conrath, U.; Beckers, G.J.M.; Langenbach, C.J.G.; Jaskiewicz, M.R. Priming for Enhanced Defense. Annu. Rev. Phytopathol. 2015, 53, 97-119. [CrossRef]

11. Mauch-Mani, B.; Baccelli, I.; Luna, E.; Flors, V. Defense Priming: An Adaptive Part of Induced Resistance. Annu. Rev. Plant Biol. 2017, 68, 485-512. [CrossRef]

12. Heil, M.; Karban, R. Explaining Evolution of Plant Communication by Airborne Signals. Trends Ecol. Evol. 2010, 25, 137-144. [CrossRef]

13. Arimura, G.; Matsui, K.; Takabayashi, J. Chemical and Molecular Ecology of Herbivore-Induced Plant Volatiles: Proximate Factors and Their Ultimate Functions. Plant Cell Physiol. 2009, 50, 911-923. [CrossRef]

14. Hu, L.; Zhang, K.; Wu, Z.; Xu, J.; Erb, M. Plant Volatiles as Regulators of Plant Defense and Herbivore Immunity: Molecular Mechanisms and Unanswered Questions. Curr. Opin. Insect Sci. 2021, 44, 82-88. [CrossRef]

15. Weeraddana, C.D.S.; Manolii, V.P.; Strelkov, S.E.; de la Mata, A.P.; Harynuk, J.J.; Evenden, M.L. Infection of Canola by the Root Pathogen Plasmodiophora brassicae Increases Resistance to Aboveground Herbivory by Bertha Armyworm, Mamestra configurata Walker (Lepidoptera: Noctuidae). Plant Sci. 2020, 300, 110625. [CrossRef]

16. International Organisation of Vine and Wine (OIV, 2017). Available online: https://www.oiv.int/public/medias/5888/endistribution-of-the-worlds-grapevine-varieties.pdf (accessed on 17 December 2021).

17. Petretto, G.L.; Mercenaro, L.; Urgeghe, P.P.; Fadda, C.; Valentoni, A.; Del Caro, A. Grape and Wine Composition in Vitis vinifera L. cv. Cannonau Explored by GC-MS and Sensory Analysis. Foods 2021, 10, 101. [CrossRef]

18. Previtali, P.; Dokoozlian, N.; Capone, D.L.; Wilkinson, K.L.; Ford, C.M. Exploratory Study of Sugar and C 6 Compounds in Single Berries of Grapevine (Vitis vinifera L.) cv. Cabernet Sauvignon throughout Ripening. Aust. J. Grape Wine Res. 2021, 27, 194-205. [CrossRef]

19. Rahman, F.U.; Nawaz, M.A.; Liu, R.; Sun, L.; Jiang, J.; Fan, X.; Liu, C.; Zhang, Y. Evaluation of Volatile Aroma Compounds from Chinese Wild Grape Berries by Headspace-SPME with GC-MS. Food Sci. Technol 2021. [CrossRef]

20. Matarese, F.; Cuzzola, A.; Scalabrelli, G.; D'Onofrio, C. Expression of Terpene Synthase Genes Associated with the Formation of Volatiles in Different Organs of Vitis vinifera. Phytochem. 2014, 105, 12-24. [CrossRef]

21. Lawo, N.C.; Weingart, G.J.F.; Schuhmacher, R.; Forneck, A. The Volatile Metabolome of Grapevine Roots: First Insights into the Metabolic Response upon Phylloxera Attack. Plant Physiol. Biochem. 2011, 49, 1059-1063. [CrossRef]

22. Zito, P.; Scrima, A.; Sajeva, M.; Carimi, F.; Dötterl, S. Dimorphism in Inflorescence Scent of Dioecious Wild Grapevine. Biochem. Syst. Ecol. 2016, 66, 58-62. [CrossRef]

23. Brantjes, N.B.M. Pollinator Attraction of Vitis vinifera subsp. Silvestris. VITIS J. Grapevine Res. 2016, 17, 229. [CrossRef]

24. Zito, P.; Serraino, F.; Carimi, F.; Tavella, F.; Sajeva, M. Inflorescence-Visiting Insects of a Functionally Dioecious Wild Grapevine (Vitis vinifera subsp. sylvestris). Genet. Resour Crop. Evol. 2018, 65, 1329-1335. [CrossRef]

25. Algarra Alarcon, A.; Lazazzara, V.; Cappellin, L.; Bianchedi, P.L.; Schuhmacher, R.; Wohlfahrt, G.; Pertot, I.; Biasioli, F.; Perazzolli, M. Emission of Volatile Sesquiterpenes and Monoterpenes in Grapevine Genotypes Following Plasmopara viticola Inoculation in Vitro: VOCs of Grapevines with Plasmopara viticola. J. Mass Spectrom. 2015, 50, 1013-1022. [CrossRef]

26. Chitarrini, G.; Soini, E.; Riccadonna, S.; Franceschi, P.; Zulini, L.; Masuero, D.; Vecchione, A.; Stefanini, M.; Di Gaspero, G.; Mattivi, F.; et al. Identification of Biomarkers for Defense Response to Plasmopara viticola in a Resistant Grape Variety. Front. Plant Sci. 2017, 8, 1524. [CrossRef]

27. Lazazzara, V.; Bueschl, C.; Parich, A.; Pertot, I.; Schuhmacher, R.; Perazzolli, M. Downy Mildew Symptoms on Grapevines Can Be Reduced by Volatile Organic Compounds of Resistant Genotypes. Sci. Rep. 2018, 8, 1618. [CrossRef]

28. Ricciardi, V.; Marcianò, D.; Sargolzaei, M.; Maddalena, G.; Maghradze, D.; Tirelli, A.; Casati, P.; Bianco, P.A.; Failla, O.; Fracassetti, D.; et al. From Plant Resistance Response to the Discovery of Antimicrobial Compounds: The Role of Volatile Organic Compounds (VOCs) in Grapevine Downy Mildew Infection. Plant Physiol. Biochem. 2021, 160, 294-305. [CrossRef] 
29. Chalal, M.; Winkler, J.B.; Gourrat, K.; Trouvelot, S.; Adrian, M.; Schnitzler, J.-P.; Jamois, F.; Daire, X. Sesquiterpene Volatile Organic Compounds (VOCs) Are Markers of Elicitation by Sulfated Laminarine in Grapevine. Front. Plant Sci. 2015, 6, 1-9. [CrossRef]

30. Tasin, M.; Anfora, G.; Ioriatti, C.; Carlin, S.; De Cristofaro, A.; Schmidt, S.; Bengtsson, M.; Versini, G.; Witzgall, P. Antennal and Behavioral Responses of Grapevine Moth Lobesia botrana Females to Volatiles from Grapevine. J. Chem. Ecol. 2005, $31,77-87$. [CrossRef]

31. Giacomuzzi, V.; Cappellin, L.; Nones, S.; Khomenko, I.; Biasioli, F.; Knight, A.L.; Angeli, S. Diel Rhythms in the Volatile Emission of Apple and Grape Foliage. Phytochemistry 2017, 138, 104-115. [CrossRef]

32. Velásquez, A.; Valenzuela, M.; Carvajal, M.; Fiaschi, G.; Avio, L.; Giovannetti, M.; D’Onofrio, C.; Seeger, M. The Arbuscular Mycorrhizal Fungus Funneliformis mosseae Induces Changes and Increases the Concentration of Volatile Organic Compounds in Vitis vinifera cv. Sangiovese Leaf Tissue. Plant Physiol. Biochem. 2020, 155, 437-443. [CrossRef] [PubMed]

33. Loughrin, J.H.; Potter, D.A.; Hamilton-Kemp, T.R.; Byers, M.E. Diurnal Emission of Volatile Compounds by Japanese BeetleDamaged Grape Leaves. Phytochemistry 1997, 45, 919-923. [CrossRef]

34. Lucchi, A.; Sambado, P.; Royo, A.B.J.; Bagnoli, B.; Benelli, G. Lobesia botrana Males Mainly Fly at Dusk: Video Camera-Assisted Pheromone Traps and Implications for Mating Disruption. J. Pest. Sci. 2018, 91, 1327-1334. [CrossRef]

35. Stellwaag, F. Neue Forschungen über Mottenflug, Eiablage und Dauer der Traubenwickler. Der Dtsch. Weinbau 1943, 22, $203-206$.

36. Gessler, C.; Pertot, I.; Perazzolli, M. Plasmopara viticola: A Review of Knowledge on Downy Mildew of Grapevine and Effective Disease Management. Phytopathol. Mediterr. 2011, 50, 3-44.

37. Jordão, A.M.; Botelho, R.V. Vitis: Biology and Species, 1st ed.; Nova Science Publishers: Hauppauge, NY, USA, 2020.

38. Pacifico, S.; D'Abrosca, B.; Scognamiglio, M.; Gallicchio, M.; Potenza, N.; Piccolella, S.; Russo, A.; Monaco, P.; Fiorentino, A. Metabolic Profiling of Strawberry Grape (Vitis $\times$ labruscana cv. 'Isabella') Components by Nuclear Magnetic Resonance (NMR) and Evaluation of Their Antioxidant and Antiproliferative Properties. J. Agric. Food Chem. 2011, 59, 7679-7687. [CrossRef]

39. Hildebrandt, A.; Guillamón, M.; Lacorte, S.; Tauler, R.; Barceló, D. Impact of Pesticides Used in Agriculture and Vineyards to Surface and Groundwater Quality (North Spain). Water Res. 2008, 42, 3315-3326. [CrossRef]

40. Fantke, P.; Friedrich, R.; Jolliet, O. Health Impact and Damage Cost Assessment of Pesticides in Europe. Environ. Intern. 2012, 49, 9-17. [CrossRef]

41. Schusterova, D.; Hajslova, J.; Kocourek, V.; Pulkrabova, J. Pesticide Residues and Their Metabolites in Grapes and Wines from Conventional and Organic Farming System. Foods 2021, 10, 307. [CrossRef]

42. Brilli, F.; Loreto, F.; Baccelli, I. Exploiting Plant Volatile Organic Compounds (VOCs) in Agriculture to Improve Sustainable Defense Strategies and Productivity of Crops. Front. Plant Sci. 2019, 10, 264. [CrossRef]

43. Kigathi, R.N.; Weisser, W.W.; Reichelt, M.; Gershenzon, J.; Unsicker, S.B. Plant Volatile Emission Depends on the Species Composition of the Neighboring Plant Community. BMC Plant Biol. 2019, 19, 58. [CrossRef]

44. Dini, I.; Marra, R.; Cavallo, P.; Pironti, A.; Sepe, I.; Troisi, J.; Scala, G.; Lombari, P.; Vinale, F. Trichoderma Strains and Metabolites Selectively Increase the Production of Volatile Organic Compounds (VOCs) in Olive Trees. Metabolites 2021, 11, 213. [CrossRef]

45. Joos, P.E.; Godoi, A.F.L.; De Jong, R.; de Zeeuw, J.; Van Grieken, R. Trace Analysis of Benzene, Toluene, Ethylbenzene and Xylene Isomers in Environmental Samples by Low-Pressure Gas Chromatography-Ion Trap Mass Spectrometry. J. Chromatogr. A 2003, 985, 191-196. [CrossRef]

46. Castro-Marín, A.; Buglia, A.G.; Riponi, C.; Chinnici, F. Volatile and Fixed Composition of Sulphite-Free White Wines Obtained after Fermentation in the Presence of Chitosan. LWT 2018, 93, 174-180. [CrossRef]

47. Rid, M.; Markheiser, A.; Hoffmann, C.; Gross, J. Waxy Bloom on Grape Berry Surface Is One Important Factor for Oviposition of European Grapevine Moths. J. Pest. Sci. 2018, 91, 1225-1239. [CrossRef]

48. Portillo-Estrada, M.; Ariza-Carricondo, C.; Ceulemans, R. Outburst of Senescence-Related VOC Emissions from a Bioenergy Poplar Plantation. Plant Physiol. Biochem. 2020, 148, 324-332. [CrossRef]

49. Alex, A.A.; Dommun, D.F.; Kubmarawa, D.; Okechukwu, J.O.; Victor, E.I. Antioxidant Activities And Phytochemical Screening Of Peanut (Arachis hypogea) Leaves. Afr. J. Environ. Nat. Sci. Res. 2020, 3, 28-37.

50. Junior, S.B.; Henrique Março, P.; Valderrama, P.; Cardoso Damasceno, F.; Silvana Aranda, M.; Alcaraz Zini, C.; Bastos Caramão, E.; Melo, A.M.T.; Teixiera Filho, J.; Teixeira Godoy, H. Analysis of Volatile Compounds in Capsicum spp. by Headspace Solid-Phase Microextraction and GC $\times$ GC-TOFMS. Anal. Methods 2015, 7, 521-529. [CrossRef]

51. Schade, F.; Legge, R.L.; Thompson, J.E. Fragrance Volatiles of Developing and Senescing Carnation Flowers. Phytochemistry 2001, 56, 703-710. [CrossRef]

52. Gfrerer, E.; Laina, D.; Gibernau, M.; Fuchs, R.; Happ, M.; Tolasch, T.; Trutschnig, W.; Hörger, A.C.; Comes, H.P.; Dötterl, S. Floral Scents of a Deceptive Plant Are Hyperdiverse and Under Population-Specific Phenotypic Selection. Front. Plant Sci. 2021, 12, 1910. [CrossRef]

53. Tabanca, N.; Kürkcüoglu, M.; Baser, K.H.C.; Tümen, G.; Duman, H. Composition of the Essential Oils of Satureja spinosa L. J. Essent. Oil Res. 2004, 16, 127-128. [CrossRef]

54. Forlani, G.; Occhipinti, A.; Bossi, S.; Bertea, C.M.; Varese, C.; Maffei, M.E. Magnaporthe oryzae Cell Wall Hydrolysate Induces ROS and Fungistatic VOCs in Rice Cell Cultures. J. Plant Physiol. 2011, 168, 2041-2047. [CrossRef]

55. Germinara, G.S.; Pistillo, M.; Griffo, R.; Garonna, A.P.; Di Palma, A. Electroantennographic Responses of Aromia bungii (Faldermann, 1835) (Coleoptera, Cerambycidae) to a Range of Volatile Compounds. Insects 2019, 10, 274. [CrossRef] 
56. Schorkopf, D.L.P. Male Meliponine Bees (Scaptotrigona aff. depilis) Produce Alarm Pheromones to Which Workers Respond with Fight and Males with Flight. J. Comp. Physiol. A 2016, 202, 667-678. [CrossRef]

57. Wang, Y.; Li, H.-Q.; Gao, X.-T.; Lu, H.-C.; Peng, W.-T.; Chen, W.; Li, S.-D.; Li, S.-P.; Duan, C.-Q.; Wang, J. Influence of Attenuated Reflected Solar Radiation from the Vineyard Floor on Volatile Compounds in Cabernet Sauvignon Grapes and Wines of the North Foot of Mt. Tianshan. Food Res. Int. 2020, 137, 109688. [CrossRef]

58. Arimura, G.; Shiojiri, K.; Karban, R. Acquired Immunity to Herbivory and Allelopathy Caused by Airborne Plant Emissions. Phytochemistry 2010, 71, 1642-1649. [CrossRef]

59. Weeraddana, C.; Wise, I.; Lamb, R.; Wolfe, S.; Wist, T.; McCartney, C.; Costamagna, A. A Laboratory Method for Mass Rearing the Orange Wheat Blossom Midge, Sitodiplosis mosellana (Diptera: Cecidomyiidae). Can. Entomol. 2021, 153, 828-836. [CrossRef]

60. Birkett, M.A.; Bruce, T.J.; Martin, J.L.; Smart, L.E.; Oakley, J.; Wadhams, L.J. Responses of Female Orange Wheat Blossom Midge, Sitodiplosis mosellana, to Wheat Panicle Volatiles. J. Chem. Ecol. 2004, 30, 1319-1328. [CrossRef]

61. Zeng, L.; Wang, X.; Kang, M.; Dong, F.; Yang, Z. Regulation of the Rhythmic Emission of Plant Volatiles by the Circadian Clock. Int. J. Mol. Sci. 2017, 18, 2408. [CrossRef]

62. Tingey, D.T.; Manning, M.; Grothaus, L.C.; Burns, W.F. The Influence of Light and Temperature on Isoprene Emission Rates from Live Oak. Physiol. Plant 1979, 47, 112-118. [CrossRef]

63. Schuh, G.; Heiden, A.C.; Hoffmann, T.; Kahl, J.; Rockel, P.; Rudolph, J.; Wildt, J. Emissions of Volatile Organic Compounds from Sunflower and Beech: Dependence on Temperature and Light Intensity. J. Atmos. Chem. 1997, 27, 291-318. [CrossRef]

64. Ghirardo, A.; Koch, K.; Taipale, R.; Zimmer, I.; Schnitzler, J.-P.; Rinne, J. Determination of de Novo and Pool Emissions of Terpenes from Four Common Boreal/Alpine Trees by ${ }^{13} \mathrm{CO}_{2}$ Labelling and PTR-MS Analysis. Plant Cell Environ. 2010. [CrossRef] [PubMed]

65. Kono, A.; Shimizu, T. Leaf Trichomes as an Effective Structure for Disease Resistance: The Case of Grapevine Downy Mildew. Jpn. Agric. Res. Q. JARQ 2020, 54, 293-298. [CrossRef]

66. Özer, N.; Şabudak, T.; Özer, C.; Gindro, K.; Schnee, S.; Solak, E. Investigations on the Role of Cuticular Wax in Resistance to Powdery Mildew in Grapevine. J. Gen. Plant Pathol. 2017, 83, 316-328. [CrossRef]

67. Markus Lange, B.; Turner, G.W. Terpenoid Biosynthesis in Trichomes-Current Status and Future Opportunities. Plant Biotechnol. J. 2013, 11, 2-22. [CrossRef]

68. Tissier, A.; Morgan, J.A.; Dudareva, N. Plant Volatiles: Going 'In' but Not 'Out' of Trichome Cavities. Trends Plant Sci. 2017, 22, 930-938. [CrossRef]

69. Gershenzon, J.; Dudareva, N. The Function of Terpene Natural Products in the Natural World. Nat. Chem. Biol. 2007, 3, 408-414. [CrossRef]

70. Yazaki, K.; Arimura, G.; Ohnishi, T. ‘Hidden' Terpenoids in Plants: Their Biosynthesis, Localization and Ecological Roles. Plant Cell Physiol. 2017, 58, 1615-1621. [CrossRef]

71. Rosenkranz, M.; Chen, Y.; Zhu, P.; Vlot, A.C. Volatile Terpenes-Mediators of Plant-to-Plant Communication. Plant J. 2021, 108, 617-631. [CrossRef]

72. Mofikoya, A.O.; Bui, T.N.T.; Kivimäenpää, M.; Holopainen, J.K.; Himanen, S.J.; Blande, J.D. Foliar Behaviour of Biogenic Semi-Volatiles: Potential Applications in Sustainable Pest Management. Arthropod-Plant Interact. 2019, 13, 193-212. [CrossRef]

73. Copolovici, L.; Niinemets, Ü. Temperature Dependencies of Henry's Law Constants for Different Plant Sesquiterpenes. Chemosphere 2015, 138, 751-757. [CrossRef]

74. Vallat, A.; Gu, H.; Dorn, S. How Rainfall, Relative Humidity and Temperature Influence Volatile Emissions from Apple Trees in Situ. Phytochemistry 2005, 66, 1540-1550. [CrossRef]

75. Wang, X.; Tao, Y.; Wu, Y.; An, R.; Yue, Z. Aroma Compounds and Characteristics of Noble-Rot Wines of Chardonnay Grapes Artificially Botrytized in the Vineyard. Food Chem. 2017, 226, 41-50. [CrossRef]

76. Wilson, C.L.; Solar, J.M.; El Ghaouth, A.; Wisniewski, M.E. Rapid Evaluation of Plant Extracts and Essential Oils for Antifungal Activity Against Botrytis cinerea. Plant Dis. 1997, 81, 204-210. [CrossRef]

77. Santino, A.; Poltronieri, P.; Mita, G. Advances on Plant Products with Potential to Control Toxigenic Fungi: A Review. Food Addit. Contam. 2005, 22, 389-395. [CrossRef]

78. Frost, C.J.; Mescher, M.C.; Dervinis, C.; Davis, J.M.; Carlson, J.E.; De Moraes, C.M. Priming Defense Genes and Metabolites in Hybrid Poplar by the Green Leaf Volatile Cis-3-hexenyl Acetate. New Phytol. 2008, 180, 722-734. [CrossRef]

79. Rodov, V.; Nafussi, B.; Ben-Yehoshua, S. Essential oil components as potential means to control Penicillium digitatum Pers. (Sacc.) and other postharvest pathogens of citrus fruit. Fresh Prod. 2011, 5, 43-50.

80. Ameye, M.; Audenaert, K.; De Zutter, N.; Steppe, K.; Van Meulebroek, L.; Vanhaecke, L.; De Vleesschauwer, D.; Haesaert, G.; Smagghe, G. Priming of Wheat with the Green Leaf Volatile Z-3-Hexenyl Acetate Enhances Defense against Fusarium graminearum But Boosts Deoxynivalenol Production. Plant Physiol. 2015, 167, 1671-1684. [CrossRef]

81. Hachlafi, N.E.; Aanniz, T.; Menyiy, N.E.; Baaboua, A.E.; Omari, N.E.; Balahbib, A.; Shariati, M.A.; Zengin, G.; Fikri-Benbrahim, K.; Bouyahya, A. In Vitro and in Vivo Biological Investigations of Camphene and Its Mechanism Insights: A Review. Food Rev. Int. 2021, 1-28. [CrossRef]

82. Di Francesco, A.; Ugolini, L.; Lazzeri, L.; Mari, M. Production of Volatile Organic Compounds by Aureobasidium pullulans as a Potential Mechanism of Action against Postharvest Fruit Pathogens. Biol. Control 2015, 81, 8-14. [CrossRef] 
83. Quintana-Rodriguez, E.; Morales-Vargas, A.T.; Molina-Torres, J.; Ádame-Alvarez, R.M.; Acosta-Gallegos, J.A.; Heil, M. Plant Volatiles Cause Direct, Induced and Associational Resistance in Common Bean to the Fungal Pathogen Colletotrichum lindemuthianum. J. Ecol. 2015, 103, 250-260. [CrossRef]

84. Ninkovic, V.; Dahlin, I.; Vucetic, A.; Petrovic-Obradovic, O.; Glinwood, R.; Webster, B. Volatile Exchange between Undamaged Plants-A New Mechanism Affecting Insect Orientation in Intercropping. PLoS ONE 2013, 8, e69431. [CrossRef] [PubMed]

85. Zhang, H.; Mallik, A.; Zeng, R.S. Control of Panama Disease of Banana by Rotating and Intercropping with Chinese Chive (Allium tuberosum Rottler): Role of Plant Volatiles. J. Chem. Ecol. 2013, 39, 243-252. [CrossRef] [PubMed]

86. Li, X.; de Boer, W.; Zhang, Y.; Ding, C.; Zhang, T.; Wang, X. Suppression of Soil-Borne Fusarium Pathogens of Peanut by Intercropping with the Medicinal Herb Atractylodes lancea. Soil Biol. Biochem. 2018, 116, 120-130. [CrossRef]

87. Lv, J.; Dong, Y.; Dong, K.; Zhao, Q.; Yang, Z.; Chen, L. Intercropping with Wheat Suppressed Fusarium Wilt in Faba Bean and Modulated the Composition of Root Exudates. Plant Soil 2020, 448, 153-164. [CrossRef]

88. Luo, C.; Ma, L.; Zhu, J.; Guo, Z.; Dong, K.; Dong, Y. Effects of Nitrogen and Intercropping on the Occurrence of Wheat Powdery Mildew and Stripe Rust and the Relationship with Crop Yield. Front. Plant Sci. 2021, 12, 637393. [CrossRef]

89. Kulakiotu, E.K.; Thanassoulopoulos, C.C.; Sfakiotakis, E.M. Biological Control of Botrytis cinerea by Volatiles of 'Isabella' Grapes. Phytopathology 2004, 94, 924-931. [CrossRef]

90. Kulakiotu, E.K.; Thanassoulopoulos, C.C.; Sfakiotakis, E.M. Postharvest Biological Control of Botrytis cinerea on Kiwifruit by Volatiles of [Isabella] Grapes. Phytopathology 2004, 94, 1280-1285. [CrossRef]

91. Tessarin, P.; Parpinello, G.P.; Rombolà, A.D. Physiological and Enological Implications of Postveraison Trimming in an OrganicallyManaged Sangiovese Vineyard. Am. J. Enol. Vitic. 2018, 69, 59-69. [CrossRef]

92. Zeng, W.; Melotto, M.; He, S.Y. Plant Stomata: A Checkpoint of Host Immunity and Pathogen Virulence. Curr. Opin. Biotechnol. 2010, 21, 599-603. [CrossRef] 